\title{
INCORPORATING AMBIGUITY INTO GIRLHOOD EXPERIENCES: GENDER STEREOTYPES AND IDENTITY NEGOTIATIONS IN MARY HELEN PONCE'S HOYT STREET AND NORMA E. CANTU'S CANÍCULA: SNAPSHOTS OF A GIRLHOOD EN LA FRONTERA ${ }^{1}$
}

\author{
ANDREA FERNÁNDEZ-GARCÍA \\ Universidad de Oviedo \\ fernandezgandrea@uniovi.es
}

Received 18 May 2020

Accepted 11 November 2020

\section{KEYWORDS}

Canicula; Hoyt Street; girlhood; Chicana identity; post-Borderlands theory; gender stereotypes; ambiguity.

\section{PALABRAS CLAVE}

Canícula; Hoyt Street; niñez; identidad Chicana; teoría postBorderlands; estereotipos de género; ambigüedad.

\begin{abstract}
This paper reconsiders the Chicana girlhood narratives of Mary Helen Ponce and Norma E. Cantú, Hoyt Street and Canicula respectively, as instances of the ambiguous gender identities that lie at the core of much post-Borderlands theory. Drawing on Jose Esteban Muñoz's theory of disidentification, Jennifer Ayala's concept of "mothering in the borderlands" and Gloria Anzaldúa's latest insights on liminality and fluidity, I contend that the female characters of the novels under analysis enter into a contradictory dialogue with the patriarchal archetypes of the mother, the virgin and the whore. Thus, this paper departs from previous feminist approaches to these texts, which have disregarded the characters' allegiance and non-allegiance to patriarchal discourses on Chicana
\end{abstract}

\footnotetext{
${ }^{1}$ Financial assistance for this essay was provided by the R\&D Project "Strangers and Cosmopolitans: Alternative Worlds in Contemporary Literature" (RTI2018-097186-BI00), funded by the Spanish National Research Program; and the Research Group Intersecciones
} 
femininity. My aim with this essay is to advance new readings of these girlhood narratives as well as to contribute to research into the fragmentary and largely evasive character of Chicana identities.

\section{RESUMEN}

Este ensayo reconsidera las novelas chicanas Hoyt Street y Canícula, escritas por Mary Helen Ponce y Norma E. Cantú respectivamente, como ejemplos de las identidades ambiguas a menudo abordadas en la teoria post-Borderlands. Apoyándome en la teoría de la desidentificación de José Esteban Muñoz, el concepto de "mothering in the borderlands" de Jennifer Ayala y las últimas teorizaciones de Gloria Anzaldúa sobre la liminalidad y la ambigüedad, sostengo que los personajes femeninos de las novelas analizadas establecen un diálogo contradictorio con los arquetipos patriarcales de la madre, la virgen y la puta. Esta interpretación se aleja, pues, de los análisis feministas realizados hasta entonces, caracterizados por su escasa atención a cómo los personajes femeninos aceptan y rechazan los discursos dominantes sobre la identidad chicana. Con todo ello mi intención es contribuir al desarrollo de la crítica literaria sobre estas novelas y al de las investigaciones sobre el carácter fragmentario y evasivo de las identidades chicanas.

\section{INTRODUCTION: ENGAGING CONTRADICTIONS IN CHICANA GIRLHOOD STORIES}

Gloria Anzaldúa's Borderlands/La Frontera: The New Mestiza (1987) has been crucial in revealing the fragmentary character of Chicana identities, inspiring subsequent generations of gender and queer theorists to reconfigure dominant tropes of that category by placing the focus on ambiguity and destabilization. Integral to this task has been Anzaldúa's notion of a mestiza consciousness, which has been further elaborated in works such as Carla Trujillo's Living Chicana Theory (1998), José Esteban Muñoz's Disidentifications: Queers of Color and the Performance of Politics (1999) and T. Jackie Cuevas's Post-Borderlandia: Chicana Literature and Gender Variant Critique (2018) to provide insight into how hegemonic understandings of Chicana and Latina identity are negotiated and displaced. Rooted in Anzaldúa's growing-up experiences in the Mexico-Texas border, a mestiza consciousness denotes the capacity to negotiate seemingly conflicting frameworks in a way that neither of them is discarded or subsumed by a larger whole (Anzaldúa Borderlands 101-102). To illustrate this ability, which results from living in cultural, gender, racial and language borderlands, Anzaldúa 
recalls a time in her adolescence when she had to mediate between Chicanx patriarchal expectations of female subservience and more emancipatory gender roles:

Though our mothers, the culture gave us mixed messages. No voy a dejar que ningún pelado desgraciado maltrate a mis hijos. And in the next breath it would say, La mujer tiene que hacer lo que diga el hombre. Which was it to be-strong, or submissive, rebellious or conforming? (40)

In this sense, the author goes on to explain that she developed a desire to become an educated and autonomous young woman while feeling constant pressure from patriarchal scripts to adopt the traditional roles of wife and mother (39-40). Therefore, it can be argued that Anzaldúa's girlhood revolved around the simultaneous embrace and rejection of patriarchal schemas, showcasing an ambiguity that problematizes essentialist and simplistic understandings of Chicana identity.

An ambiguous and contradictory negotiation of patriarchal expectations is also present in various Chicana coming-of-age narratives dealing with girlhood experiences, which include Sandra Cisneros' The House on Mango Street (1984), Emma Pérez's Gulf Dreams (1996) and Felicia Luna Lemus's Trace Elements of Random Tea Parties (2003). Structured as a series of vignettes, Cisneros' work tells the story of Esperanza, a girl who straddles the line between personal independence and reliance on collectively accepted rules of female domesticity, wifehood and maternity. The nameless main character of Pérez's narrative, for her part, falls in love with a married woman in a male-dominated culture that limits the contingencies of female sexual expression. Similarly, Leticia, the protagonist of Lemus's text, wishes to find a place in the Los Angeles lesbian hipster scene while also feeling pressured to conform to the model of compulsory heterosexuality. Thus, these three narratives portray girls who feel compelled to fulfil the terms of the heterosexual contract while taking an interest in life paths that divert from heteropatriarchal scripts, exercising a subjectivity as flexible and elusive as the mestiza consciousness. ${ }^{2}$ In this paper I seek to prove that an ambiguous negotiation of patriarchal discourses can be also attributed to the female characters in the following Chicana girlhood

\footnotetext{
${ }^{2}$ For an in-depth analysis of the identity development of these female characters, see Bolaki (2011), Araújo Duarte de Gouvea (2018) and Garcia-Avello (2018).
} 
narratives: Mary Helen Ponce's Hoyt Street: An Autobiography (1993) and Norma E. Cantú's Canícula: Snapshots of a Girlhood en la Frontera (1995).

\section{HOYT STREET AND CANÍCULA: A LOOK AT WOMEN, CULTURE AND COMMUNITY}

Hoyt Street and Canícula are coming-of-age narratives told through vignettes that revolve around Ponce's and Cantú's growingup experiences in the Chicanx barrio of Pacoima and the MexicoTexas borderlands during the first half of the twentieth century. Hence, they deal with Chicana characters in their path to adulthood, which brings to the fore some important and interconnected issues, namely otherness, cultural conflict, gender roles and the quest for identity. Besides sharing similar thematic concerns, these texts have a common scope and purpose. As a matter of fact, both adopt an autoethnographic perspective that aims at examining and uplifting their respective communities from the point of view of the subaltern (Bellver Sáez "La infancia"; McCracken "Hybridity"; Gutiérrez y Muhs Communal Feminisms; Garcia "Transculturation"). Thereby, they give an account of Pacoima and the Mexico-Texas borderlands as seen from girls embedded in those particular cultural contexts, contesting and decolonizing the Euro-American ethnographic tradition, which has traditionally propagated damaging depictions of people of color. From this follows that Mary Helen and Nena, the main characters/narrators in Hoyt Street and Canícula, not only focus on their own individual experiences, but also provide powerful insights regarding their communities so as to revalorize them. In this last respect, emphasis is placed mainly on the women that people these communities, which is an expression of the authors' feminist consciousness. Cantú makes this clear in an article on the writing of Canicula: "The feminist in me consciously included the strong women - the mothers, grandmothers, aunts, comadres [...]. I wanted to tell the stories of women who survived, who struggled" ("The Writing" 105). While Ponce has not made, to my knowledge, a similar statement regarding Hoyt Street, several scholars point out the feminist potential of the text, which relies on its rich insights on the role of women in Pacoima (see Bellver Sáez "La infancia"; Kabalen de Bichara Telling). Canicula and Hoyt Street can therefore be considered women's stories where Nena's and Mary Helen's lives are 
interwoven with those of other women in their communities, widening understandings of their respective cultural milieus.

Despite the relevance of women in these narratives, most scholarly attention has been paid to other issues. The vast majority of the studies on Canicula explore how it complicates the boundaries between fact and fiction, genres and disciplines (see Adams "Heightened"; Castillo and Tabuenca Córdoba Border Women; Birkhofer "Norma"), whereas scholars dealing with Hoyt Street -which, unlike Cantú's work, continues to be an understudied textconcentrate on the thorough insights on the routine and character of barrio life that lie at the center of the narrative (see Tatum Chicano; Garcia "Transculturation"). Feminist analyses on these texts are not only scarce but also somewhat limited. In this sense, they examine women's repression in a Chicanx patriarchal context (see Bellver Sáez "La infancia") or, alternatively, concentrate on the female characters' resistance to male-dominated culture (see Chang "The Hidden Curriculum"; Sibaja García "The Alternative Lives"), failing to consider how women's embrace of patriarchal morals coexist with stories of transgression. Only Kabalen de Bichara's Telling Border Stories: Four Mexican American Women Writers (2013), which includes an analysis of Ponce's text, gives readers a glimpse into Mary Helen's allegiance and non-allegiance of patriarchal scripts by considering how she takes for granted the role of women as homemakers while at the same time competing with boys on the playground and wishing to work outside the home. My reading of Canicula and Hoyt Street moves in this direction, focusing on the conflicting Mexican American femininities portrayed in the texts. ${ }^{3}$

In particular, this essay concentrates on the female characters' ambiguous dialogue with the patriarchal paradigm that Chicana feminists label the "Tres Marias Syndrome" (Gaspar de Alba et al. Three Times). Linked with the three Marys who attended Jesus at his crucifixion -the Virgin Mary/Guadalupe, who is paradoxically virgin and mother, and Mary Magdalene, the reformed whore from whom La Malinche descended- this patriarchal discourse categorizes Chicanas according to three stereotypes: the virgin, the mother and the whore. Cantú's and Ponce's simultaneous rejection and embrace of these roles will be analyzed in the light of Chicanx/Latinx feminist

3 The terms "Chicanx" and "Mexican American" are used interchangeably throughout this essay to refer to people of Mexican ancestry born and/or raised in the United States. 
and queer thought. Although this essay takes Anzaldúa's notion of the mestiza consciousness as a point of departure, I am fully aware of how trite this concept is in the field of Chicanx/Latinx feminist theory. For this reason, the analysis below moves beyond this notion and emphasizes instead more contemporary theorizations of the gendered self as inherently fluid and ambiguous. Of particular relevance in this regard will be José Esteban Muñoz's theory of disidentification (1999), Jennifer Ayala's notion of "mothering in the borderlands" (2006) and Anzaldúa's latest insights on liminality and fluidity (2015), all of which carry on the legacy of Borderlands. On the other hand, it will be also necessary to consider concepts such as marianismo and malinchismo to scrutinize the role of patriarchal mores in Mary Helen's and Nena's communities. All this will enable a better understanding of the characters' ambiguous gender identities, leading us to consider the way they destabilize the unity and coherence integral to gender and cultural hierarchies.

The sections below are arranged according to the gender stereotypes referred to above. Hence, the third section will examine how Mary Helen, Nena and other women in their communities simultaneously embody and reject the archetypical Chicana mother, whereas the fourth one will explore how female characters straddle between the patriarchal roles of the virgin and the whore. In conducting such analysis, this essay seeks to contribute to scholarship on Hoyt Street and Canicula as well as to research into the fragmentary and largely evasive character of Chicana identities.

\section{MOTHERING IN THE BORDERLANDS: A COMPLEX DIALOGUE WITH CHICANX PATRIARCHY}

Although Chicana identities are fluid and heterogeneous, growing up Chicana often means negotiating a set of patriarchal gender-role expectations. As a wide array of scholars in US social literature argue, one of the most important of these expectations to which Chicana girls should adhere is to become mothers, ensuring that social reproduction of coming generations is successful (see Gil and Vazquez The Maria Paradox; Sequeira The Machismo). The ideology of marianismo is of uttermost importance in this regard, as it dictates norms for acceptable maternal behavior in a Latinx/Chicanx patriarchal context. Originating in Spain and introduced into Latin America by the conquest, this male-dominated discourse conveys the idea that a good mother should emulate the 
Incorporating Ambiguity Into Girlhood Experiences: Gender Stereotypes And Identity Negotiations In Mary Helen Ponce's Hoyt Street And Norma E. Cantú's

Virgin Mary/Guadalupe in her purity and sacrifices. Under this view, girls and women should therefore aspire to become self-sacrificing mothers, long-suffering and submissive, devoted to homemaking (Lopez-Baez "Marianismo"; Sequeira The Machismo). ${ }^{4}$ These patriarchal understandings of mothers and mothering work shape female socialization processes in Mary Helen's and Nena's communities. As we will see below, these gender expectations are fulfilled and also challenged, complicating existing dominant cultural ideals of Chicana femininity.

The narratives under scrutiny showcase how females in Pacoima and the Mexico-Texas borderlands are socialized to perform mothering functions, exercising great control over their social roles. This socialization has profound effects on girls' formal education. In this sense, Mary Helen explains that, while boys are encouraged to continue with their education after finishing elementary school, girls are forced to abandon their studies because it is assumed that they "would not need a diploma to change diapers" (Ponce 313). While Nena is not as explicit as Mary Helen in stating that girls' future reproductive functions limit their access to education, she depicts a community governed by the very same norms. Proof of that is the major role that childbearing and childrearing activities play in the lives of most female characters and the scarce existence of highschool educated women in the community, showing that for females mothering comes before education. These patriarchal biases unveil that women in Mary Helen's and Nena's birthplaces gain importance mostly through biological and social/cultural reproduction, which is seen in this context as necessarily precluding educational, political, social and economic advancement.

In addition to restricting access to secondary education, the socialization of female characters into the mothering role also affects the way they experience family and community life. In this regard, the texts under analysis show that the act of caring and nurturing children is not only enacted by birth mothers, but also by sisters, grandmothers, aunts or girlfriends. This unique familial arrangement

${ }^{4}$ Other than prescribing rules for appropriate maternal performance, marianismo also dictates behavioral norms for "good" virginal girls, as will be shown in the next section. The influence and applicability of this patriarchal discourse is therefore broader. In fact, it is widely referred to in the literature as articulating the "ideal of true femininity" that Chicanas/Latinas are supposed to embody, which is characterized by dependent, submissive and passive demeanors. For more information, see Gil and Vazquez (2002). 
of surrogate mothering and extended kinship, which is a common aspect in Chicanx, African American and Native American communities, comes into being as a result of gender, racial and class oppression (Mercado-López "Chicana Mothering"; Feagin and Feagin Racial). Thus, in Chicanx poverty-stricken communities such as Nena's and Mary Helen's, extended family members such as grandmothers or close girlfriends may assist with the childcare responsibilities while the mother works as a means of overcoming socioeconomic marginality. Prompted by these circumstances, Nena's mother takes care of Frances, her goddaughter; Tía Licha is like a mother to Nena, and Mary Helen is looked after by Doña Luisa, an old widow who helps her mother with the younger children.

Although the aforementioned examples refer to adult women only, Canícula and Hoyt Street also expose how interlocking systems of oppression urge Nena and Mary Helen to actively participate in this familial arrangement of surrogate mothering. Significantly, their grandmothers and mothers are the women who contribute the most to socializing the protagonists into the mothering role, thus acting as cultural transmitters. As much scholarship on the intersections of gender, ethnicity and nationalism sustains (see Yuval-Davis and Anthias Woman; Yuval-Davis Gender), women in patriarchal contexts are regarded as biological and cultural reproducers of the nation. According to this view, females are traditionally responsible for teaching the next generation of citizens the cultural traditions and ideologies of the nation. Interpellated by these patriarchal ideologies, Nena's maternal grandmother-referred to as Bueli-and Mary Helen's mother urge the main characters to care for and protect their little brothers and sisters. The vignettes "Bueli" and "Azalia" are illustrative of Bueli's significance as a gendered socializing agent. The former recalls how Nena's dying grandmother reminds the protagonist of her role as a surrogate mother to Azalia, her threemonth-old sister. "Cuida la niña," Bueli tells Nena on the eve of her death, devoting herself to the teaching of mothering until her last days (Cantú 34). The vignette "Azalia" evidences the power Bueli's last lesson has had on Nena, who feels proud that she successfully protected Azalia, as she was asked to do: "See, Bueli, I did take care of her" (36). The protagonist pronounces these words the day of Azalia's wedding, a special occasion in which she reflects upon how she helped her sister become a healthy and kind young woman. The words the protagonist directs to her late grandmother evidence, 
therefore, that she has somehow internalized the gendered norms of mothering.

Mary Helen is socialized into mothering functions by Vicenta, her mother, who asks her to take care of Josey, "the baby of the family" (Ponce 36). Nonetheless, when compared with Canicula, Ponce's text allocates considerably less narrative space to account for Mary Helen's role as a surrogate mother to her baby brother. In fact, readers are only told about the protagonist's satisfaction at being an authoritarian figure to Josey: "I was his leader; Josey was my follower [...]. He always obeyed without complaining" (36). This stands in stark opposition to the attitude shown by Nena, who understands the seriousness of her mothering responsibilities. Yet, even if Mary Helen experiences mothering in quite an amusing way, the text shares with Canicula an interest in telling how pervading and commanding the act of caring and nurturing children is for women in the community. In this sense, it has to be noted that although extended mothering arrangements are crucial in keeping these communities functioning in the face of poverty and marginalization, they rely on the patriarchal view that the care of children is to be performed by females only, reinforcing in turn the seemingly natural link between women and childrearing. Hence, I contend that the two narratives under analysis unveil an oppressive hierarchy in both family and community that lays mothering responsibilities on nearly all women regardless of their age, limiting to a great extent their opportunities and experiences.

On the other hand, Hoyt Street and Canícula portray instances in which mothering is inextricably linked to long-suffering devotion to children. This characteristic is something that the protagonists identify in many women of their surroundings. Of relevance in this regard is Mary Helen's description of her neighbor Magda: "Doña Magda was a typical Mexican mother who loved her son with a passion. It was said of her, 'es una santa; sufre por su hijo,' she suffers for her son. On our street, this was the ultimate compliment to a mother" (Ponce 73-74). Here, Mary Helen acknowledges suffering as an intrinsic aspect of good maternal behavior in Pacoima, a characteristic that is also embodied by Nena's mother, Tina and Pifania; the three comadres: "The three comadres sharing worries [...]. They weep for their children's failures, layoffs, divorces, dropouts, miscarriages, drugs, fights, DWIs, fines, alcoholism, family disturbance calls" (Cantú 47-48). These 
observations show that the capacity to bear the unbearable for the sake of one's children puts mothers' individual wishes and well-being second, foregrounding the power and strength of marianismo in molding their subjectivities.

Chicanx patriarchal ideologies are also responsible for building up family spaces where power is unevenly distributed between the father and the mother. Under this androcentric view, the father is the unquestioned head of the family (Villarruel and Chahin "Beyond"). As such, he exercises control over his wife and children and the decisions made by him are marked as final and binding (Villarruel and Chahin "Beyond"). This domineering behavior on the part of fathers can be understood as an expression of Chicanx machismo, which is predominately linked to an exaggerated masculinity and male chauvinism (Tarrant Men). From this perspective, the ideal image of a man is someone who is strong, virile and in personal control of people and things. In this sense, much scholarship in the area of US social literature emphasizes that these social and cultural expectations frequently lead men to behave in despotic and oppressive ways toward women, giving rise to violent situations in which the latter are coerced physically and morally (see Gutmann The Meanings; Sequeira The Machismo; Tarrant Men). In order for these gendered expectations to materialize effectively, they have to be complemented by marianismo, which, as shown earlier, translates into a submissive behavior on the part of women. From this follows that men's authoritarian behavior necessitates women's unconditional submission to be successful. Mary Helen's home and Nena's grandfather's place in Monterrey are built upon these patriarchal schemas, although there are instances in which such gender asymmetries are reversed, as we will see later. Thus, Mary Helen's father and Nena's paternal grandfather, referred to as Tranquilino and Papagrande respectively, act as enforcers of discipline and primary policy makers, often leaving their wives with nothing to say about specific issues, especially those related to sexuality.

These power dynamics are revealed when Mary Helen exposes her mother's felt obligation to submit to sex whenever Tranquilino pleases. Despite the fact that they sleep in separate rooms to avoid unwanted pregnancies, Vicenta is often waken up by her husband's demand for sex:

Still my father, a healthy man in his forties, often sneaked into my 
mother's bedroom. I once saw him near her bed. I heard him say the word "tetas," but did not understand this Spanish word. When I lingered to talk with my mother, he quickly left the room. My mother, who was taking her afternoon nap, appeared relieved. (Ponce 8-9)

Had it not been for Mary Helen's interruption, Vicenta would have had to comply with her husband's wishes, giving way to an oppressive situation in which her agency is totally obliterated for the sake of Tranquilino's pleasure. Here we can see how machismo and marianismo are at work, complementing each other. On the one hand, Tranquilino acts in accordance with the discourse of machismo when he requires his wife to submit to his sexual desires. To meet her husband's demand, Vicenta must remain submissive and selfless, conforming to marianismo.

Patterns of male domination and female subordination are discerned in Nena's family when her cousin Elisa is expelled from Papagrande's house. This decision is made by Papagrande and Elisa's father, Tío Chuy, after she a has a baby out of wedlock at the age of sixteen. Deeply influenced by patriarchal discourses that see childbearing and marriage as inextricably linked, Papagrande and Tío Chuy choose to move Elisa to Saltillo, preventing their wives from having a say in such a hard decision. In so doing, they reveal the patriarchal structures governing the family. ${ }^{5}$

However pervading male-dominated understandings of mothers and mothering work are in Pacoima and the Mexico-Texas borderlands, it is important to note that they are not always incontestably accepted by Mary Helen, Nena and the rest of the female characters. In fact, I shall argue that they interrogate these patriarchal narratives in two different ways: first, by widening women's cultural and social roles; and second, by showing more egalitarian relationships between mothers and fathers.

Mary Helen and Nena contest the compelling belief that women gain importance only through biological and social/cultural reproduction by aspiring to and embodying other practices that are not associated with mothering. As a girl who takes an interest in education, Mary Helen looks up to her learned elder sisters Nora and Elizabet. The former is described as "an intellectual, a seeker of

\footnotetext{
5 This episode will be analyzed again in the next section. In this case, emphasis will be placed on the virgin-whore dichotomy that underlies Elisa's expulsion.
} 
knowledge, a buyer of books" (19), whereas the latter is praised for being one of the first Chicanas in the area to earn a business major in high school and become a secretary. In a community where girls are expected to drop out of school to help out at home and form their own families, Nora's thirst for knowledge and Elizabet's academic and professional achievements stand as a gender abnormality. Yet, in behaving like this, they open and validate an alternative path for their little sister, who learns that young women can perform roles other than mothering. Although Hoyt Street ends when Mary Helen is twelve years old, the note from the author that precedes the narrative confirms that she went on to do something beyond procreation and the care and nurture of a family. In this regard, she went to college, where she started to write her autobiography as part of a research project. Later on, she became a professor of creative writing, which she combined with her career as a writer, showing that, just like her sisters, she also followed an intellectual and professional trajectory. A similar path is taken by Nena, who, despite gender prejudices and institutional racism, pursues higher studies and gets a job as a copy editor at a newspaper.

Hoyt Street and Canícula also contain episodes where decisions are negotiated between the father and the mother, challenging the power structures that deem the former as the undisputed patriarch. Aware of the oppression that many of her girlfriends have to endure at the hands of their male relatives, Vicenta asks Tranquilino to help Eufemia, who lives in near poverty as a consequence of her husband's acts. As the head of the family, Eufemia's husband, Falcon, manages the money that he makes in Tranquilino's wood business, spending most of it on pies and cakes. To put an end to this irresponsible behavior, Vicenta suggests to her husband that Falcon's pay be sent directly to Eufemia, which Tranquilino reluctantly accepts to do:

I felt that perhaps my father knew that eating cakes made Falcón happy and a good worker, so he allowed for this. More than that, he felt that women should not meddle in the affairs of men. Nonetheless my mother was determined to do what in her eyes she felt was right. (89)

This episode shows that Tranquilino's role as the family patriarch does not always remain unchallenged, opening up a space of negotiation in which his wife's suggestion is discussed and 
accepted. In this case Vicenta is presented as an influential figure in matters from which she has always been excluded, thereby reversing the patriarchal hierarchy in which mothers are placed in a subservient position to fathers.

In spite of having been raised in Papagrande's house, which is ruled in a sexist manner, Nena's father-referred to as Papi-helps to build a family space in accordance with egalitarian patterns. In this sense, not only is he attentive to his wife's needs, but also thinks she is entitled to spend her own money in any way she likes, even if he finds some of her purchases to be "indecent". This occurs when Nena's mother-referred to in the story as Mami-gets her daughter a new pair of shoes that make her look like a whore in Papi's eyes. ${ }^{6}$ Even though he expresses his uneasiness about the purchase, he does not overrule his wife's decision as an authoritarian father would have done: "But Mami's is on my side, after all we spent her hardearned money on the shoes, so I keep the shoes but wear them rarely" (Cantú 82). The family engages, then, in a negotiation that ends up asserting Mami's right to spend her salary as she pleases, which challenges the patriarchal discourses that give mothers a secondary role within the family.

Throughout this section we have seen that girls in Pacoima and the Mexico-Texas borderlands are socialized into believing that selfless and submissive mothering is women's main social function and natural role. At the same time, however, Mary Helen, Nena and other female characters learn that there may also be room for education and a professional career for women, regardless of whether or not they mother any children. Furthermore, they find out that more egalitarian relationships between fathers and mothers are possible. Thus, they both embrace and challenge the archetypical Chicana mother, unveiling an ambiguity that lies at the core of Anzaldúa's mestiza consciousness. However, even if these slippages and contradictions can be interpreted within the framework of a mestiza mindset, I argue that a more productive reading of these ambiguous negotiations is possible thanks to Jennifer Ayala's concept of "mothering in the borderlands" (2006) and José Esteban Muñoz's theory of disidentification (1999).

Drawing on Anzaldúa's insights on the negotiation of multiple worlds, expert in educational psychology Jennifer Ayala proposes the

\footnotetext{
${ }^{6}$ Papi's reliance on the virgin-whore dichotomy to categorize Nena's behavior will be
} discussed in the next section. 
aforementioned term to examine the contradictions inherent in the context of Latina mothering in the United States. As an illustrating example of these dissonances, she refers to Latina mothers who teach their daughters about the possibility of independence from men through education while telling them that men are needed for their protection (Ayala 35). Such contradictions, which involve both critique and loyalty to patriarchal cultural scripts, are perceived as "efforts to survive within the system while also finding ways of quietly subverting the system" (Ayala 31). Hence, Latina women often find themselves interrogating and succumbing to patriarchal discourses of mothering and femininity in an attempt to balance reality with possibility-the reality of gender oppression and the possibility of transcending it. Significantly for our purposes, Ayala's reading recognizes that the threshold position inhabited by Latina mothers is not a comfortable and safe space, but a location where they have to grapple with power dynamics. Thus, this conceptualization overcomes one of the major shortcomings of Anzaldúa's mestiza consciousness, which has been criticized for its celebratory nomadology and for remaining oblivious to the power differentials between dominant and subjugated cultures (see Muñoz Disidentifications; Cuevas Post-Borderlandia). Considering all this, it can be contended that the characters' ambiguous embrace of prevailing cultural scripts about mothering may represent active efforts to interrupt Chicanx patriarchy, an act which, far from being carried out abstractly, involves negotiating dynamics of oppression.

An acknowledgement of power relations lies also at the core of Muñoz's theory of disidentification, which, although not addressing the performance of mothering roles, provides us with illuminating insights on the transfiguration of dominant cultural forms that can further enrich the above analysis. Muñoz advances this theory to explain how queer performers of color mediate the dominant culture by transforming it for their own purposes rather than adhering to the dominant culture's mandates for so-called appropriate forms of Latinx identity. He states that disidentification is about "cultural, material and psychic survival. It is a response to state and global power apparatuses that employ systems of racial, sexual and national subjugation [...]. Disidentification is about managing and negotiating historical trauma and systemic violence" (161). To illustrate this process, he explains that, in Latinx drag queen acts, the marginalized individual incorporates and transfigures 
heterosexist and racist cultural forms to challenge and rewrite their closed terms (138-141). Such ambiguous negotiation of power dynamics allows the minoritized subject to disidentify with dominant forms of white femininity, which are subsequently reconfigured into alternative femininities (138-141). Even if queer performers of color are not at the center of this essay, I believe that the way Mary Helen, Nena and other female characters identify with and against the archetypical Chicana mother somewhat mirrors the workings of Muñoz's theory of disidentification. In this regard, it can be argued that their simultaneous embrace and rejection of prevailing discourses of mothering involves an active disidentification with dominant forms of Mexican American femininity. Thus, in addition to evidencing the complex circulation of power at play here, Muñoz's theory helps us see how this ambiguous embrace of patriarchal discourses paves the way for the reconfiguration of dominant tropes of a Chicana identity, challenging any efforts at imposing unitary paradigms of selfhood.

\section{VIRGINS VS. WHORES: NEGOTIATING HONOR AND SHAME}

Besides entering into a complex dialogue with the mother archetype, Mary Helen and Nena have to negotiate the virgin/whore dichotomy, which governs and disciplines Chicana sexuality in a patriarchal context. At the center of this binary are the discourses of marianismo and malinchismo. As suggested earlier, the former urges girls to be demure, obedient daughters who wait until marriage to have sex. On the other hand, malinchismo, or female treachery, is a discourse aimed at repressing and denigrating those women in Mexican and Chicanx contexts who step out of the realm of patriarchal control. With its origins in the figure of La Malinche, the Indian mistress and interpreter of conqueror Hernán Cortés, the discourse of malinchismo has given way to the gendered position of the "bad" woman in Mexican and Chicanx cultures. The denigration of La Malinche as a treacherous figure is most famously seen in Octavio Paz's essay "Los Hijos de la Malinche," included in the collection El laberinto de la soledad (1950). In it, Paz accuses La Malinche of passively giving herself to the enemy and extends this alleged passivity to all women (35). By this logic, this female figure and all women are held responsible for the violations done to her, to themselves and to Mexico. Malinchismo is therefore connected to the betrayal of the Mexican people by the alleged passiveness and 
lasciviousness of La Malinche, which led to the stigmatization of female sexuality (Moraga Loving; Gaspar de Alba "Malinche's Revenge"). This reviled figure, then, serves as a counterpoint to the revered Virgin of Guadalupe, the indigenous counterpart of the Virgin Mary. ${ }^{7}$

Therefore, not following the marianismo ideals of premarital chastity, self-sacrifice and submissiveness puts Chicana girls in line with the patriarchal fabrication of the treacherous Malinche, ostracizing and shaming them for behaving in ways that are perceived as "foreign" to the culture. The pages that follow explore how Mary Helen, Nena and other girls negotiate these opposing patriarchal archetypes, which brings to the fore aspects such as honor and shame. In this sense, great emphasis will be placed on how their behavior as good virginal girls coexists with their "betrayal" of patriarchal sexual mores, which occurs either when showing sexual conducts deemed as inappropriate or when criticizing the power structures that stigmatize female sexuality. As we will see below, their inability to fully embrace one archetype or the other complicates the dichotomy that denies, silences and contains female sexual subjectivity within Chicanx patriarchal contexts.

Mary Helen's and Nena's negotiation of the patriarchal script goes parallel to perceived changes in their anatomies, such as the growth of breasts and body hair, and new biological processes, namely, menstruation. In the context of Mexican American patriarchy, menstruation before marriage translates to a denial of female sexuality and a shame concerning the female sexual body (Hurtado Voicing; Zavella "Playing"; Ayala "Confianza"; Blake Chicana Sexuality). The virgin/whore dichotomy is at work here. On the one hand, girls are expected to refrain from sex until they get married. Their virginity is in fact considered as the repository of the family's honor (Zavella 248). Hence, its loss often leads to the ostracization of the girls by their own relatives. Therefore, those who do not guard their sexual purity carry the stone of shame; they are regarded as whores. This connects to a sense of shame that many Chicanas feel towards menstruation. These feelings are shaped by the

\footnotetext{
7 Chicana feminists have revisited La Malinche in a more positive light. They have done so by portraying her as a victim of historical circumstances and recognizing her power and knowledge, expressed through her translating abilities. For more information, see Norma Alarcón's “Chicana's Feminist Literature: A Re-Vision through Malintzin/or Malintzin: Putting Flesh Back on the Object" (1981).
} 
aforementioned patriarchal belief in La Malinche's betrayal of her people by sleeping with the enemy; the original shame that resulted in the Spanish conquest of Mexico ( $\mathrm{Paz}$ El Laberinto) and the stigmatization of female sexuality (Moraga Loving; Gaspar de Alba "Malinche's Revenge").

Shame and the denial of female sexuality are paramount aspects in the socialization of girls in Pacoima and the Mexico-Texas borderlands once they become "señoritas," a term that alludes to their sexually related responsibilities. On the one hand, Mary Helen observes that menstruation is never called by its name. These observations are recorded in the vignette "It," whose very title is a euphemism used in Pacoima to refer to menstruation. Together with the adjective "sick," they are used to soften the negative connotations given to this biological process. This is revealed many times, for example when Mary Helen and two other friends ask Virgie to play kickball with them:

"Can Virgie come out?"

"No."

"Por qué?"

"Ummm, she's sort of sick..."

Virgie, I was told, could not play for at least three days; I immediately knew why. So did Mundo and Concha. Virgie had it! (Ponce 334)

A similar atmosphere of secrecy and taboo is unveiled when Cantú's alter ego is caught unprepared for her period at school, an embarrassing incident included in the vignette "First Period." "iQué vergüenza!" (Cantú 87) is everything that the protagonist can say after her menstrual blood stains her clothes, which she tries to hide by sitting at the nurse's office until it is time to go home. This demonstrates that Nena has learned that menstruation is something one keeps to herself, reason why she avoids being noticed by her classmates because of her period. It can therefore be contended that "It" and "First Period" testify to how menstrual shame translates into a strict control of female sexuality. That is, in imbuing menstruation with a sense of embarrassment, patriarchal discourses urge these girls to control and conceal their periods. Such silencing limits and denies their sexuality, keeping them virgins.

Nena and Mary Helen are fully aware of the bad consequences that follow the display of sexual behaviors deemed as inappropriate in a patriarchal setting, which speaks about the power of 
malinchismo in their communities. In this sense, I shall argue that Canicula and Hoyt Street showcase the different, although related, ways in which this patriarchal discourse operates. On the one hand, as will be shown below, it condemns girls who do not guard their sexual purity to social ostracism. On the other hand, it instills in young women fears of being labeled as treacherous whores. These fears seek to lead female characters down the "proper" gender path, exerting a great of power over their choices.

Nena becomes familiar with the reality of social rejection in the vignettes "Elisa" and "Cowboy Boots", which focus on the undesirable consequences that the loss of virginity before marriage has for female teenagers in a patriarchal context. The protagonists of these pieces are Elisa and Sanjuana, Nena's cousin and friend respectively, whose "transgressions" leave them vulnerable to the experience of social exclusion. Yet, even if the disgrace that befalls these girls can be said to serve as cautionary tales for Nena, I contend that there is no condemnation or rejection of these "dishonorable" acts, but a sense of injustice that Cantú's alter ego manages to convey in her narration. The first of these pieces revolves around Elisa's expulsion from her grandfather's house after having a baby at the age of sixteen. As said in the previous section, Elisa's out-of-wedlock pregnancy leads Papagrande and Tío Chuy to dismiss her for shaming her beloved ones. These events earn Elisa the designation as the black sheep of the family, which Nena challenges by referring to her as her favorite cousin. Thus, far from joining her family in their despising of her cousin or simply rejecting her transgression for all the negative consequences that follow, the protagonist displays sympathy and admiration towards Elisa, a woman who, despite having been cast out of the family, has managed to build a life of her own.

In "Cowboy Boots," Nena explains how she develops a sort of sixth sense regarding her knowledge and understanding that Sanjuana has been raped by Tom, the man with the cowboy boots. "Sanjuana never said anything, but I knew" (171) points towards the capacity, or facultad, that allows Nena to discover the truth behind Sanjuana's out-of-wedlock pregnancy. In Anzaldúa's words, la facultad is:

the capacity to see in surface phenomena the meaning of deeper realities, to see the deep structure below the surface. It is an instant "sensing," a quick perception arrived at without conscious 
reasoning. It is an acute awareness mediated by the part of the psyche that does not speak, that communicates in images and symbols which are the faces of feelings, that is, behind which feelings reside/hide. The one possessing this sensitivity is excruciatingly alive to the world. (Borderlands 60)

La facultad is a survival mechanism, an intuitive form of knowledge that is often developed by those who have been disempowered, or to quote Anzaldúa, "pushed out of the tribe for being different" (60). It arises, then, as a response to racism, homophobia, sexual violence and other forms of oppression. Thus, Nena's own experiences of patriarchal oppression allow her to better grasp Sanjuana's real circumstances. Nena's understanding stands opposed to the ignorance and lack of sensitivity shown by most people in her community. In fact, almost everyone takes sides with the rapist. Helen, Tom's wife, verbally assaults Nena's friend, holding her responsible for the abuse and subsequent pregnancy. Sanjuana's mother, for her part, sends her to Nuevo Laredo, showing a fanatism that makes her reject her own daughter. Nena finds this situation extremely unfair: "I wanted to go kill him [...]. I was so upset I couldn't even look at him" (172). The protagonist's contempt against Tom renders the latter as the only one who should be subjected to public scrutiny and moral judgment, thereby criticizing the power structures that stigmatize female sexuality and validate violence against them.

While "Elisa" and "Cowboy boots" illustrate how malinchismo alienates those girls who lose their virginity before marriage, there are other episodes pertaining to non-marital relationships and clothing styles that show how this discourse directs girls' choices by playing with their fears of being labeled as whores. In her account of her sister Elizabet, Mary Helen explains how she ceases to be an obedient, virgin daughter in her parents' eyes: “And then Elizabet fell from grace; she eloped with R., a handsome young man who wore a snappy uniform" (Ponce 22). Elizabet flees from home to get hitched by a judge, disappointing her parents, who believe that good girls should get married in a church after receiving the family blessing. However, social pressures make Elizabet go against her initial wishes, leading her down the path sanctioned by marianismo: "Later Elizabet did get married en la iglesia; otherwise the whole town would say they were living in sin" (22-23). This quote acknowledges that Elizabet does not exercise her agency freely for fear of being 
labeled as a bad girl. This coercion bothers Mary Helen, who thinks that elopement does not make her sister any worse.

Similar pressures are experienced by Nena when presented with the possibility of following conducts that could construct her as a whore. This happens after she gets the same pair of shoes as her friend Lydia:

I beg and beg Mami for a pair of black leather flats with red, green, yellow, shiny rhinestones just like Lydia's. When I finally get them, Papi wants us to take them back-they're shoes for a puta, not a decent girl. But Mami's on my side, after all we spent her hardearned money on the shoes, so I keep the shoes but wear them rarely. To church and school I wear my old scuffed oxblood-red loafers and bobby sox. I'm wearing the rhinestone flats defiantly in my quinceañera photo as I sit in our front yard with friends and family all around. (Cantú 82)

In Papi's view, the shiny leather flats are signifiers of sexual promiscuity, reason why he discourages her daughter from wearing them. Thus, Nena decides not to wear those shoes regularly, showing the impact that malinchismo has in directing her choices. At the same time, however, I contend that this episode leaves room for the transgression of patriarchy. In this sense, it can be argued that in choosing to keep the shoes but wear them only on certain occasions, Nena places herself in a liminal position that prevents others from categorizing her as either a virgin or a whore. In other words, she is enacting her capacity to juggle these seemingly conflicting stereotypes in a way that neither of them is entirely assimilated or strictly opposed, a third mode of dealing with dominant ideology that echoes Muñoz's theory of disidentification. Drawing on this notion, it can be argued that, instead of buckling under the pressures of dominant ideology (identification, assimilation) or attempting to break free of its inescapable sphere (counteridentification, utopianism), Nena's incorporation and transfiguration of the aforementioned stereotypes seeks to transform a cultural logic from within, allowing the recognition of the contradictory facet (Muñoz 11). In this regard, it is important to note that Nena does not move beyond the poles of acceptance or rejection at this point only. As has been demonstrated so far, Nena's adolescence is characterized by an ambiguous negotiation of different cultural beliefs. Distinctively, however, the episode of the shoes shows Nena consciously acknowledging her skill in juggling competing categories at a specific 
moment-she wears her old loafers for school and church, while defiantly changing to her new shoes on other special occasions.

In this section we have seen that the texts analyzed here feature female characters who engage in a complex process of disidentification with the archetypes of the virgin and the whore. On the one hand, they are socialized to behave as compliant, demure girls who guard their virginity until marriage. Nonetheless, they do not always act in accordance with these marianismo ideals. In fact, they "betray" these patriarchal mores in two different ways: by showing sexual inappropriate actions or by directly criticizing the structures that stigmatize female sexuality. In evidencing the instability of marianismo and malinchismo, these ambiguous dialogues break with the virgin/whore duality upon which dominant forms of Chicana sexuality rest. From this follows that Nena's and Mary Helen's girlhood years do not fall within the behavior parameters of either side of the binary, thus criticizing any sense of a fixed and monolithic Chicana identity. At the same time, this inability to conform to either one stereotype or the other results in the dismantling of Western dichotomous thinking. This change of paradigm constitutes the main aspect dealt with in Anzaldúa's posthumous book Light in the Dark/Luz en lo Oscuro: Rewriting Identity, Spirituality, Reality (2015), which includes a reelaboration of some of her most influential concepts, namely nepantla, conocimiento or spiritual activism. In it, Anzaldúa discusses the "perspective from the cracks" adopted by nepantleras, a term she uses to refer to those individuals that live amidst different cultures and power forces (Light 82), such as the girls analyzed in this essay. In this regard, she contends that these liminal positions give nepantleras a view from the interstices, a perspective that enables them to reconfigure themselves as subjects outside the us/them binary: "Rejecting identification with a single position, we [nepantleras] shift from one position to another, listening to all sides [...]. The nepantla mind-set eliminates polarity thinking when there's no inbetween, only 'either/or'; it reinstates 'and"' (82). Hence, as nepantleras, the characters under scrutiny in this paper refuse to adopt an unambiguous position regarding patriarchal discourses, contesting polarized binary thought. This inbetween stance, in turn, contributes to creating new stories of identity and rethinking reality.

\section{CONCLUSION}


As this point, then, it can be said that Canicula and Hoyt Street depict female identities that cannot be fully captured by any of the patriarchal stereotypes of Mexican American femininity. Although identified as Chicanas, Nena, Mary Helen and other young women in their communities reconfigure dominant tropes of that category through the simultaneous incorporation and transfiguration of maledominated understandings of Mexican American femininity, revealing the instability of the cultural discourses of marianismo and malinchismo. In reading these negotiations through a postborderlands lens, this essay has foregrounded the centrality of ambiguity in the characters' identities. Thus, this paper introduces significant nuances into Anzaldúa's long-known concept of the mestiza consciousness, which is characterized as developing "a tolerance for ambiguity" (Borderlands 100). In this regard, I contend that the above analysis underscores that ambiguity is not just tolerated by the female characters under scrutiny, but also incorporated into their own identities. This leads us to argue that their identities' stability relies, paradoxically enough, on ambiguity, liminality and fluidity. Very importantly, this view of the self contributes to shaking the foundations of essentialist paradigms of selfhood that define Chicana females according to manifold stereotypes and either/or parameters, opening up the path for the validation of more multifaceted Mexican American girlhood experiences.

On a final note, I would like to emphasize the major role that Chicana coming-of-age narratives like these play in terms of ethnic representation, given the increasing demographic growth of Mexican American girls. In this sense, I believe that conducting analysis on novels of this type brings the spotlight on a series of experiences to which an ever-increasing segment of the US population may relate. Besides, my focus on ambiguity contributes to projecting more democratic views of Chicanidad while at the same time offering new readings of the novels under analysis.

\section{WORKS CITED}

ADAMS, Timothy D. "'Heightened by Life' vs. 'Paralyzed by Fact': Photography and Autobiography in Norma Cantú's Canícula". Biography, vol. 24, no. 1, 2002, pp. 57-71. 
ALARCÓN, Norma. "Chicana's Feminist Literature: A Revision Through Malintzin/or Malintzin: Putting Flesh Back on the Subject". This Bridge Called My Back: Writings of Radical Women of Color, edited by Cherrie Moraga and Gloria Anzaldúa, Third Woman, [1981] 2002, pp. 202-211.

ANZALDÚA, Gloria E. Borderlands/La Frontera: The New Mestiza. Auntie Lute, [1987] 2007.

---. Light in the Dark/Luz en lo Oscuro: Rewriting Identity, Spirituality, Reality, edited by AnaLouise Keating, Duke UP, 2015.

ARAÚJO DUARTE DE GOUVEA, Nathália. "A Detour in Longing: Gender, Sexuality and Lesbian Desire in Carla Trujillo's What Night Brings and Emma Pérez's Gulf Dreams". Revista Estudos Feministas, vol. 26, no.3, 2018, pp. 1-9.

AYALA, Jennifer. "Confianza, Consejos and Contradictions: Gender and Sexuality Lessons between Latina Adolescent Daughters and Mothers". Latina Girls: Voices of Adolescent Strength in the U.S., edited by Jill Denner and Bianca L. Guzmán, New York UP, 2006, pp. 29-43.

BELLVER-SÁEZ, Pilar. "La infancia como pretexto: autobiografia, etnografia y autoetnografia en Hoyt Street de Mary Helen Ponce". Estudios Ingleses de la Universidad Complutense, no.9, 2001, pp. 253-271.

BIRKHOFER, Melissa. "Norma Elia Cantú's Canícula: Snapshots of a Girlhood en la Frontera". Rocky Mountain Review, 2012, pp. 48-57.

BOLAKI, Stella. Unsettling the Bildungsroman: Reading Contemporary Ethnic American Women's Fiction. Amsterdam and New York, 2011.

CANTÚ, Norma. Canicula: Snapshots of a Girlhood en la Frontera. Updated Edition. U of New Mexico P, [1995] 2015.

---. "The Writing of Canicula: Breaking Boundaries, Finding Forms". Chicana Feminisms: A Critical Reader, edited by Gabriela F. Arredondo, Aída Hurtado, Norma Klahn, and Patricia Zavella, Duke UP, 2003, pp. 97 108.

CASTILlO, Debra A. and María Socorro Tabuenca Córdoba. Border Women: Writing from La Frontera. U of Minnesota P, 2002. 
CHANG, Aurora. "The Hidden Curriculum of Canícula: Critical Educational Lessons in Becoming a Mujer". New Perspectives on Canicula and Other Works by Norma Elia Cantú, edited by Gabriella Gutiérrez y Muhs, U of Arizona P, 2017, pp. 142-157.

CISNEROS, Sandra. The House on Mango Street. Vintage Books, [1984] 2009.

CUEVAS, T. Jackie. Post-Borderlandia: Chicana Literature and Gender Variant Critique. Rutgers UP, 2018.

FEAGIN, Joe R. and Clairece Booher Feagin. Racial and Ethnic Relations, Census Update, 9th Edition. Texas A\&M University, 2018.

GARCÍA, Mario T. "Transculturation, Memory and History: Mary Helen Ponce's Hoyt Street". In International Perspectives on Chicana/o Studies: 'This World is My Place,' edited by Catherine Leen and Niamh Thornton, Routledge, 2014, pp. 35-48.

GARCÍA-AVELLO, Macarena. Nuevos horizontes en la literatura de Estados Unidos: Transnacionalismos, resistencias queer y sus manifestaciones en la web. Edicions UIB, 2018.

GASPAR DE ALBA, Alicia. "Malinche's Revenge”. Feminism, Nation and Myth: La Malinche, edited by Rolando Romero and Amanda Nolacea Harris, Arte Público Press, 2005, pp. 44-57.

GASPAR DE ALBA, Alicia, María Herrera-Sobek and Demetria Martínez. Three Times a Woman: Chicana Poetry. Bilingual Review Press, 1989.

GIL, Rosa Maria and Carmen Inoa Vazquez. The Maria Paradox: How Latinas Can Merge Old World Traditions with New World Self-Esteem. G. P. Putnam's Sons, 2002.

GUTIÉRREZ Y MUHS, Gabriella. Communal Feminisms: Chicanas, Chilenas and Cultural Exile: Theorizing the Space of Exile, Class and Identity. Lexington, 2007.

GUTMANN, Matthew. The Meanings of Macho: Being a Man in Mexico City. U of California P, [1996] 2006.

HURTADO. Voicing Chicana Feminisms: Young Women Speak Out on Sexuality and Identity. New York UP, 2003. 
KABALEN DE BICHARA, Donna M. Telling Border Life Stories: Four Mexican American Women Writers. Texas UP, 2013.

LEMUS, Felicia Luna. Trace Elements of Random Tea Parties. Seal Press, 2003.

LOPEZ-BAEZ, Sandra. 1999. "Marianismo". In Key Words in Multicultural Interventions: A Dictionary, edited by Jeffery S. Mio, Joseph E. Trimble, Patricia Arredondo, Harold E. Cheatham and David Sue, Greenwood, 1999, p. 183.

MCCRACKEN, Ellen. "Hybridity and the Space of the Border in the Writing of Norma Elia Cantú". Studies in the 20th Century Literature, vol. 25, no. 1, 2001, pp. 261-280.

MERCADO-LÓPEZ, Larissa M. 2010. "Chicana Mothering”. In Encyclopaedia of Motherhood, edited by Andrea O'Reilly, SAGE, 2010, pp. 177-179.

MORAGA, Cherrie. Loving in the War Years/Lo que nunca pasó por sus labios. South End, 1993.

MUÑOZ, José Esteban. Disidentifications: Queers of Color and the Performance of Politics. U of Minnesota Press, 1999.

PAZ, Octavio. El laberinto de la soledad. Fondo de Cultura Económica, 1950.

PÉREZ, Emma. Gulf Dreams. Aunt Lute Books, 1996.

PONCE, Mary Helen. Hoyt Street: An Autobiography. U of New Mexico P, 1993.

SEQUEIRA, David. The Machismo and Marianismo Tango. Dorrance, 2009.

SIBAJA GARCÍA, Carlos. "The Alternative Lives of Azucena in Norma Elia Cantú's Canícula". New Perspectives on Canicula and Other Works by Norma Elia Cantú, edited by Gabriella Gutiérrez y Muhs, U of Arizona P, 2017, pp. 158-167.

TARRANT, Shira. Men Speak Out: Views on Gender, Sex and Power. Routledge, 2008.

TRUJILlO, Carla, ed. Living Chicana Theory. Third Woman Press, 1998. 
VILLARRUEL, Francisco A. and Jaime Chahin. "Beyond the Myths: Paternal Values of Latino Fathers". Michigan Family Review, vol. 3, no. 1, 1998, 17-30.

YUVAL-DAVIS, Nira. Gender and Nation. SAGE, 1997.

YUVAL-DAVIS, Nira and Floya Anthias. Woman-Nation-State. Palgrave Macmillan, 1989.

ZAVELLA, Patricia. "Playing with Fire': The Gendered Construction of Chicana/Mexicana Sexuality". Perspectives on Las Américas: A Reader in Culture, History and Representation, edited by Mathew C. Gutmann, Félix V. Rodríguez and Lynn Stephen, Blackwell, 2003, pp. 229-244. 